\title{
Antiangiogenic Potential of Levetiracetam by Blocking N-type Voltage Gated Calcium Channels
}

\author{
Chandana Kamili1,*, Hima Sowmya Kandoti², Sunil Kumar Sarolu², Suresh Merugü ${ }^{3}$, Abbulu Konde \\ ${ }^{1}$ Assistant Manager, Medical Writing, Tata Consultancy Services, Mumbai, INDIA. \\ 2Department of Pharmacology, CMR College of Pharmacy, Hyderabad, Telangana, INDIA. \\ ${ }^{3}$ Department of Research and Development, CMR College of Engineering and Technology, Hyderabad, Telangana, INDIA. \\ ${ }^{4}$ Department of Pharmaceutics, CMR College of Pharmacy, Hyderabad, Telangana, INDIA.
}

\begin{abstract}
Objectives: Angiogenesis is generation of micro vessels. These ion channels on endothelium play vital functions in cell proliferation, migration, cell volume expansion and in related angiogenesis. Our study aims to evaluate the antiangiogenic capability of Levetiracetam, a N-type voltage gated calcium channel blocker. Methods: Anti-angiogenic activity was evaluated by MTT cell viability assay, Morphological screening assay, Zebra fish caudal fin assay and Zebra fish embryo assay using different concentrations of levetiracetam, standard drug Bevacizumab and control. The parameters assessed were percentage viability in MTT, change in the cell shape or volume microscopically in morphological screening assay, percentage regeneration of amputated fin in caudal assay and percentage neovascularization in zebra fish embryo assay. Results: The results suggest that levetiracetam treatment significantly inhibited Hep G2 cells viability and cell volume expansion, which are the further steps in the endothelial cell proliferation. Arrest in neovascularization caused various phonotypical changes in the zebra fish embryo has been captured us by microscope. A significant decrease in fin regeneration was observed. Conclusion: The findings statistically validate the antiangiogenic potential of levetiracetam. The antiangiogenic property might be due to the blocking of $\mathrm{N}$-type voltage gated calcium channels, which are largely located in the endothelial cells.
\end{abstract}

Key words: Angiogenesis, Levetiracetam, Calcium channels, Cell migration, Neovascularisation.

\section{INTRODUCTION}

Angiogenesis, which is the creation of fresh vessels from the already existing vessels, is a normal course which helps in the growth of the body, embryogenesis, development of the female reproductive system and healing of damaged tissue. ${ }^{1,2}$ It when occurs in abnormal conditions, lead to tumour progression with the help of growth factors. During transition, a tumour undergoes a critical step called angiogenesis. This results in stimulation of capillary growth and development of the ability to synthesize proteins. The most important among such proteins is vascular endothelial growth factor (VEGF). VEGF encourages endothelial cells (EC) to go through a tumour and start the process of neovascularization.
EC division further secretes growth factors that result in the development or migration of tumour cells. Consequently, ECs and tumour cells reciprocally fuel each other., ${ }^{3,4}$

Evidence suggests that angiogenesis occurs when the ratio between angiogenesis activators and angiogenesis inhibitors is less. Angiogenesis inhibitors can be seen as promising therapeutic agents to treat various types of malignancy conditions. Angiogenesis inhibitors, also known as anti-antigenic agents are the substances that block the process of angiogenesis. They interfere with the various steps in the mechanism of angiogenesis, finally stopping the formation of new blood vessels. As tumour cells need oxygen and nutrients
Submission Date: 18-05-2020; Revision Date: 16-07-2020; Accepted Date: 15-09-2020

DOI: 10.5530/ijper.54.4.200 Correspondence: Dr. Chandana Kamili, M.Pharm.

Assistant Manager, Tata Consultancy Services, Mumbai, INDIA.

Phone no: +919581140044 Email id: chandanakamili@ gmail.com

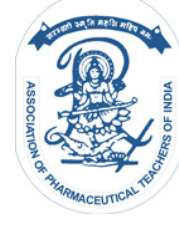

www.ijper.org 
produced by the blood vessels, interfering with this essential step leads to decreased tumour progression and hence, used as an effective approach in treating various types of malignancies..$^{5-8}$

Levetiracetam is a drug used to treat generalized, partial, myoclonic and tonic-clonic seizures. It is also effective in the treatment of wide-spectrum mental disorders related to the nervous system. It acts by irreversibly blocking the pre-synaptic high-voltage activated calcium $\left(\mathrm{Ca}^{2+}\right)$ channels, N-type $\mathrm{Ca}^{2+}$ channels, modulating potassium channels and enhancing GABA and glycine neurotransmission. ${ }^{9}$ The ion channels on endothelium take parts in a imperative deeds in proliferation and so in the associated angiogenesis. ${ }^{10}$ As $\mathrm{Ca}^{2+}$ channels contribute to cell proliferation, ${ }^{11}$ Levetiracetam was selected to evaluate its anti-angiogenic effect by various assays.

\section{MATERIALS AND METHODS}

\section{Materials}

\section{Requirements}

Levetiracetam, Bevacizumab (standard drug), 3-[4,5-dimethylthiazol-2-yl]-2,5 diphenyl tetrazolium bromide solution, Phosphate-buffered saline, $\mathrm{pH}$ 7.4, 40\% v/v Dimethylformamide, 2\% Glacial Acetic Acid, $16 \%$ Sodium Dodecyl Sulfate, $\mathrm{pH} 4.7$ and $37^{\circ} \mathrm{C}$, 96 well plate, Hep G2 cells, Complete Dulbecco's Modified Eagle (DME) Medium with 10\% fetal bovine serum, phosphate-buffered saline, cytotoxin-Doxorubicin, Human malignant melanoma (A-375) and Human lung adenocarcinoma (A549) (All the chemical and cell lines have been purchased from Sigma-Aldrich). Sensitive analytical balance, camera, Micropipette, Fluorescent microscope, $0.9 \mathrm{~mm}$ mesh (to catch embryos of zebra fish), Fish system water and tanks.

\section{Experimental animals}

Zebra fish were obtained from Scott labs Pvt Ltd, Hyderabad, kept at $28^{\circ} \mathrm{C}$ on a $10 \mathrm{hr}$ dark and $14 \mathrm{hr}$ light cycle in glass chambers. ${ }^{12}$ The fish were checked for swimming behaviour daily, body weight gain, twisted vertebral column and throughout look. Fish did not show symptoms of distress for the period of experiment.

\section{Methods \\ MTT Assay}

This cell viability method helps to assess live cells in comparatively high throughput i.e.in 96-well plates, without the want for tricky cellular counting process. So, the maximum use is to evaluate cytotoxicity of numerous chemical at different concentrations. Here, any change in viable cell count can be identified by estimating formazan concentration, which reflects a change in optical density (OD) by means of a plate reader at 540 and $720 \mathrm{~nm}$.

\section{Procedure}

MTT solution was stored and covered from light at $4^{\circ} \mathrm{C}$ and taken measures for no precipitate in the Solubilisation fluid. 25 × 103 Hep G2 cells were seeded in a 96 well plate having $250 \mu \mathrm{l}$ of DMEM. The test antiangiogenic agent was added. It was incubated for $24 \mathrm{hr}$. Medium was aspirated and washed with three times PBS. $125 \mu$ l of DMEM with $25 \mu$ l of MT'T solution was added to the well plate. Again it was incubated for $2 \mathrm{hr}$ at $37^{\circ} \mathrm{C} .100 \mu \mathrm{l}$ of solubilisation solution was then added. Absorbance was measured at $570 \mathrm{~nm}$ by spectrophotometer. ${ }^{13}$ The inhibitory rate of proliferation was calculated by:

$$
\begin{aligned}
& \text { Absorbance of sample - } \\
& \% \text { Viable cells }=\frac{\text { Absorbance of blank }}{\text { Absorbance of control }-} \times 100 \\
& \text { Absorbance of blank }
\end{aligned}
$$

\section{Morphological screening Cell culture}

A549 was used, they were sub-cultured. Cell line was maintained in $75 \mathrm{~cm}^{2}$ vented flasks with DMEM and was grown at humid environment of $5 \% \mathrm{CO}_{2}$ at $37^{\circ} \mathrm{C}$. Cell line was incubated in DME medium supplemented with 10\% fetal bovine serum, 1\% non-essential amino acids, $1 \%$ penicillin $(1000 \mathrm{U} / \mathrm{mL}), 1 \%$ streptomycin $(1000 \mu \mathrm{g} / \mathrm{mL})$ and $1 \%$ amphotericin $(250 \mathrm{U} / \mathrm{mL})$. The cell line was subculture enzymatically in $0.25 \%$ trypsin$1 \mathrm{mM}$ EDTA and passaged on $75 \mathrm{~cm}^{2}$ plastic flasks at a density of $2.2 \times 10^{4}$ cells $/ \mathrm{cm}^{2}$. Cell count was confirmed by microscopic examination.

\section{Procedure}

A-549 cells were treated with $10,20,40 \mu \mathrm{g}$ concentration of Levetiracetam and $25 \mu \mathrm{g}$ of the standard drug. As a part of antiangiogenic evaluation, we have screened various concentrations of the test drug based on the $\mathrm{LD}_{50}$ values against morphological conduct of A549. Cells were observed for 24, 48, 72 hrs, after the testing drug was added. Pictures were taken by Axiovert 200M phase contrast microscope at 10x. The software used was Axiovision Rel.4.2. ${ }^{14}$

\section{Zebra fish caudal fin assay}

Fin regeneration has mainly been studied after a simple removal of the tail fin part using an amputation 
procedure. Zebra fish were divided into five groups and grown at $28 \pm 0.5^{\circ} \mathrm{C}$ on a $14 \mathrm{hr}$ light and $10 \mathrm{hr}$ dark cycle in fish tanks. Within few hours of amputating the fin, re-epithelialisation occurs in the wound. ${ }^{15}$ Before amputations, zebra fish were anesthetized by $0.04 \%$ Tricaine. The caudal fin was amputated to approximately $50 \%$ size using a razor blade, at right angles to the cranio-caudal axis. ${ }^{14}$ Straight away the amputated fish were placed in the recovery tank and were found recovered within three min. Bevacizumab $(25 \mu \mathrm{g} / 150 \mathrm{ml})$ and Levetiracetam $(100,200$ and $400 \mu \mathrm{g} / 150 \mathrm{ml})$ were added to tanks for seven days post amputation (dpa). The length of fin regeneration was observed and the assay was repeated thrice independently with six fish per group. ${ }^{16}$

\section{Zebrafish Embryo model assay}

Zebra fish of both the sex were taken in the ratio of 2:1 and kept in separate tanks with unremitting oxygen supply. Fishes were kept without feed for 3 days after which they are fed for 7 days. On the $11^{\text {th }}$ day, both sex are kept in one tank. Fishes are kept in own tanks one day after mating and embryos were harvested use of embryo collector of mesh size $0.9 \mathrm{~mm}$.
Embryo medium was arranged by dissolving $2.94 \mathrm{~g}$ of sodium chloride, $0.13 \mathrm{gms}$ of potassium chloride, $0.49 \mathrm{gms}$ of calcium chloride, $0.81 \mathrm{~g}$ of magnesium sulphate and $10 \mathrm{~g}$ of methylene blue in 10L of fish system water. ${ }^{17}$ Embryos were washes with embryo medium and are taken in a beaker with embryo medium. A microliter plate is taken where each well is filled with $100 \mu \mathrm{L}$ of embryo medium containing blank, test $(10,20$ and $40 \mu \mathrm{g} / 100 \mathrm{ml}$ ) and standard drug. Using a dropper, embryos were transferred to the microliter plate, one embryo in a well.

After adding the drug, embryos were separately placed in culture plates at $28.5^{\circ} \mathrm{C}$ until $72 \mathrm{hr}$ post fertilization (hpf). 24, 48 and $72 \mathrm{hpf}$ of drug treatment, embryos were examined for neovascularization and also for phonotypical variations such as bending of tail, yolk sac elongation to abdominal region, vessel haemorrhages, delay in hatching, reduced growth and pericardial edema using a trinocular microscope with blue filters and photographs were saved. ${ }^{17}$

\section{RESULTS}

Morphological screening (Table 1)

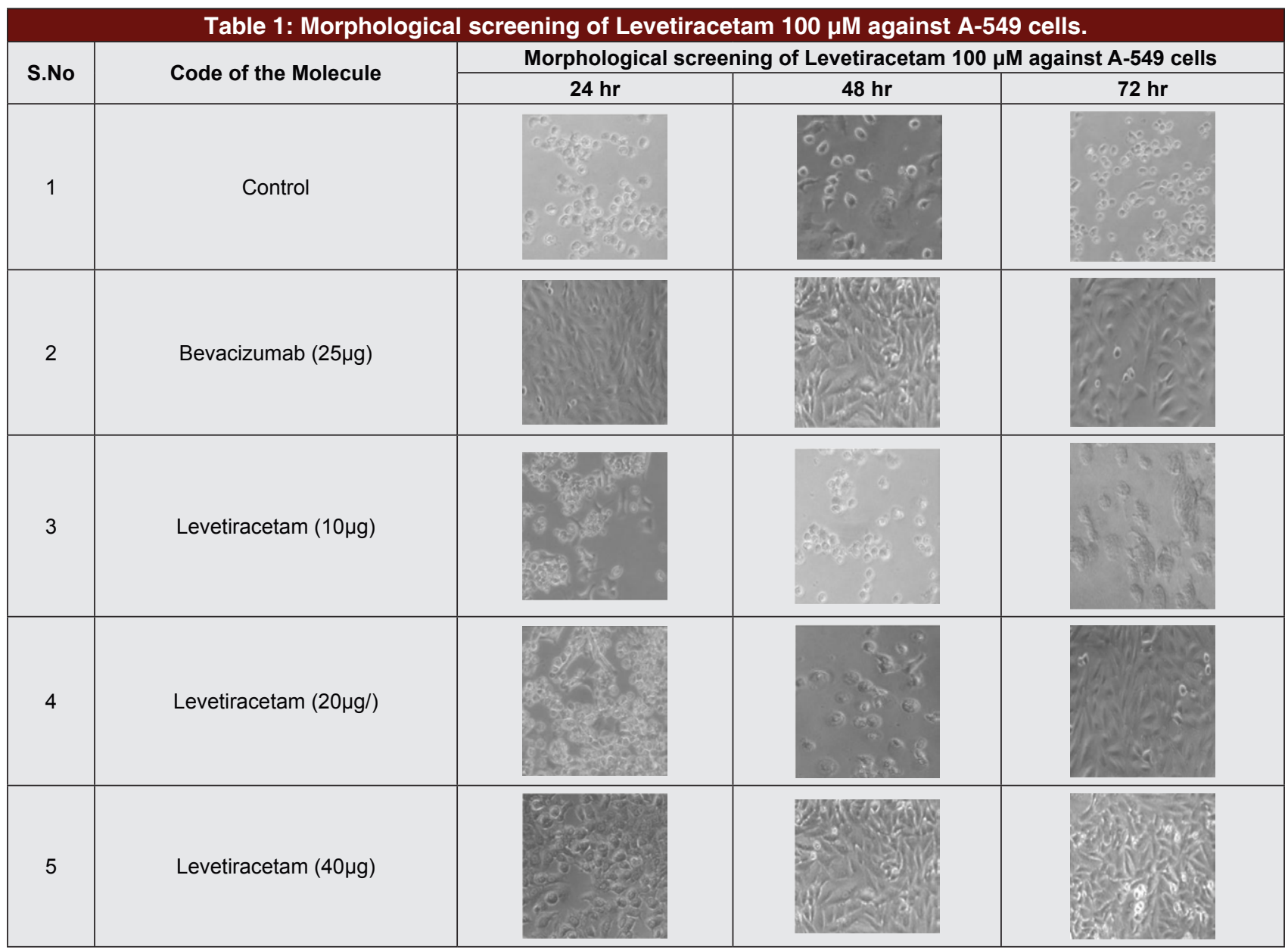




\begin{tabular}{|c|c|}
\hline \multicolumn{2}{|c|}{ Zebrafish fin assay (Table 2) (Figure 1) } \\
\multicolumn{2}{|c|}{ Table 2: Effect of treatment groups on zebrafish fin } \\
assay.
\end{tabular}

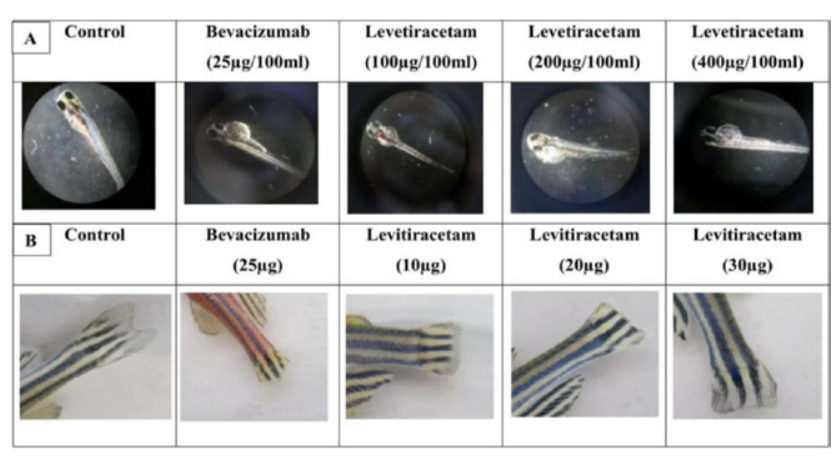

Figure 1: Effect of treatment groups on anti-angiogenic activity in A) zebra fish embryos and B) Regeneration of zebra fish fin

\section{Zebrafish embryo assay (Table 3)}

\section{Table 3: Effect of treatment groups on Zebrafish} embryo assay.

\begin{tabular}{|c|c|c|}
\hline S. No. & Treatment Groups & $\%$ Angiogenic vessels \\
\hline 1. & Control & $95.3 \pm 1.43$ \\
\hline 2. & Bevacizumab $(25 \mu \mathrm{g} / 100 \mathrm{ml})$ & $23.5 \pm 0.764^{\star * *}$ \\
\hline 3. & Levetiracetam $(10 \mu \mathrm{g} / 100 \mathrm{ml})$ & $31.5 \pm 1.88^{\star * *}$ \\
\hline 4. & Levetiracetam $(20 \mu \mathrm{g} / 100 \mathrm{ml})$ & $22.2 \pm 1.60^{\star * *}$ \\
\hline 5. & Levetiracetam $(40 \mu \mathrm{g} / 100 \mathrm{ml})$ & $15.3 \pm 1.36^{\star * *}$ \\
\hline
\end{tabular}

\section{DISCUSSION}

Angiogenesis takes place only after proliferation and migration of ECs. This significant stepladder is regulated by extracellular signals. Calcium stimulations control antigenic steps. EC moves from the existing vessels to arrange into a fresh tube. These cells go away from the vessel by shooting into matrix, proliferate and lastly end their mutagenic action. $\mathrm{Ca}^{2+}$ ions are secondary messengers mediate many signals in migration and proliferation. Scarcity of extracellular $\mathrm{Ca}^{2+}$ causes growth seize in $\mathrm{G} 1 / \mathrm{S}$ signifying $\mathrm{Ca}^{2+}$ role in cell cycle progression. Cytoplasmic level of $\mathrm{Ca}^{2+}$ ions is guarded by many mechanisms. System for calcium rule is by

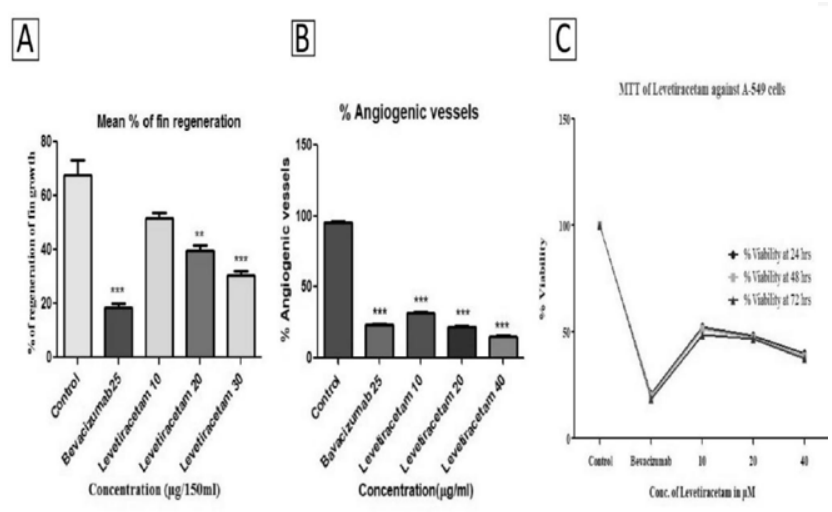

Figure 2: Graph representing action of ion channel modulators on A) Zebrafish finassay, B) Zebrafish embryo assay, C) MTT assay.

\section{MTT ASSAY (Table 4) (Figure 2)}

\begin{tabular}{|c|c|c|c|c|}
\hline S.No & Conc. in $\mu \mathrm{g}$ & $\begin{array}{c}\% \text { Viability } \\
\text { at } 24 \mathrm{hrs}\end{array}$ & $\begin{array}{c}\% \text { Viability } \\
\text { at } 48 \mathrm{hrs}\end{array}$ & $\begin{array}{c}\% \text { Viability } \\
\text { at } 72 \mathrm{hrs}\end{array}$ \\
\hline 1 & Control & 100 & 100 & 100 \\
\hline 2 & Bevacizumab & 20.69 & 19.84 & 18.42 \\
\hline 3 & 10 & 40.08 & 38.68 & 37.41 \\
\hline 4 & 20 & 48.26 & 47.29 & 47.04 \\
\hline 5 & 40 & 52.33 & 51.61 & 48.73 \\
\hline
\end{tabular}

binding to calmodulin protein is significant, resulting in the start of calcium-calmodulin-dependent protein kinases and regulate cAMP a transcriptional protein. Calcium concentration inside the cell has many functions based on its interval, amount and site. $\mathrm{Ca}^{2+}$ in endoplasmic reticulum (ER) is essential for the cell functioning. Increased levels of $\mathrm{Ca}^{2+}$ in ER stimulates cell division and vice versa. However a continued fall in the $\mathrm{Ca}^{2+}$ from ER or sudden decrease in $\mathrm{Ca}^{2+}$ from ER, concurrent with discharge of $\mathrm{ER}^{-\mathrm{Ca}^{2+}}$ into the cytosol, results apoptosis. Voltage gated channels are T-, L-, P-, N- and R-type. Amidst these, T-, L- and $\mathrm{N}$-type are central in pathological environment. Increase in calcium causes the cells shift from G1 and G2/M phases. Opening of N-type stimulate G2/M whereas L-type channel stimulate G0/G1. T-type $\mathrm{Ca}^{2+}$ channels are important in cell cycle progression. Opening of $\mathrm{Ca}^{2+}$ channels results in down regulation of depolarization at $\mathrm{G} 2 / \mathrm{M}$ phase by closing of $\mathrm{K}^{+}$channels. Thus calcium dynamics plays a key role in cell death and proliferation.

Levetiracetam irreversibly blocks high-voltage-activated (HVA) calcium by $18 \%$ on an average in newly dissected CA1 hippocampal neurons of rats. Levetiracetam 
specifically blocks $\mathrm{N}$-type $\mathrm{Ca}^{2+}$ channels of CA1 pyramidal hippocampal neurons.

Anti-angiogenic activity was evaluated by MTT cell viability assay. The results suggest that levetiracetam treatment significantly inhibited Hep G2 cells viability. The test drug is 50 percent as potent as the standard drug Bevacizumab. Morphological screening assay, Zebra fish caudal fin assay and Zebra fish embryo assay using different concentrations of Levetiracetam, standard drug Bevacizumab and control. The parameters assessed in morphological screening assay are cell shape and cell volume by microscopic examination. Cell volume expansion, which is the further steps in the endothelial cell proliferation, validates the antiangiogenic potential of the test drug. In this assay, control cells were normal with roughly cuboidal shape, Bevacizumab treated cells with increase in the incubation time, showed decrease in the cell volume hence changing the cell shape to spindle shape. Similar change in the cell shape was also observed with $40 \mu \mathrm{g}$ of levetiracetam. Percentage regeneration of amputated fin in caudal assay was calculated, significant decrease in fin regeneration was observed with the standard and test drug treated fishes. In the zebra fish embryo assay percentage neo micro vascularization was noted from the two major blood vessels, the dorsal aorta and the caudal vein. Decrease in the development of dorsal longitudinal anastomotic vessels and intersegment vessels were observed with the test and standard treated groups. ${ }^{18-21}$

\section{CONCLUSION}

Earlier studies stated the role of Levetiracetam in treating epilepsy. The present study showed a potent antiangiogenicactivity of Levetiracetam. Theresults of the study will be very useful to develop a cost-effective antiangiogenic compound. However, further research is required for suitable molecular modifications in the lead antiangiogenic drug, Levetiracetam and to deliver a site specific dosage form which can be affective against the pathological conditions resulting due to excessive angiogenesis.

\section{ACKNOWLEDGEMENT}

We thank the management of CMR College of Pharmacy to allow us to perform the research in the institution.

\section{CONFLICT OF INTEREST}

Authors declare no conflicts of interest.

\section{ABBREVIATIONS}

EC: Endothelial cells; VEGF: Vascular endothelial growth factor; OD: Optical density.

\section{REFERENCES}

1. Hillen F, Griffioen AW. Tumour vascularization: Sprouting angiogenesis and beyond. Cancer and Metastasis Reviews. 2007;26(3-4):489-502.

2. Veeramani VP, Veni G. An essential review on current techniques used in angiogenesis assays. International Journal of Pharm Tech Research. 2010;2(4):2379-87.

3. Tahergorabi Z, Khazaei M. A review on angiogenesis and its assays. Iranian Journal of Basic Medical Sciences. 2012;15(6):1110.

4. Galley HF, Webster NR. Physiology of the endothelium. British Journal of Anaesthesia. 2004;93(1):105-13.

5. Auerbach R, Lewis R, Shinners B, Kubai L, Akhtar N. Angiogenesis assays: A critical overview. Clinical Chemistry. 2003;49(1):32-40.

6. Kang YB, Mallikarjuna PR, Fabian DA, Gorajana A, Lim CL, Tan EL. Bioactive molecules: Current trends in discovery, synthesis, delivery and testing. IEJSME. 2013;7(Suppl 1):S32-46.

7. Kamili C, Kakaraparthy RS, Vattikuti UM. Anti-Angiogenic activity of flunarizine by in ovo, in vitro and in vivo assays. Turkish Journal of Pharmaceutical Sciences. 2019;16(3):303.

8. Kamili C, Beguma S, Kondaa A, Kakaraparthi RS, Vattikutti UM. NANOANTIANGIOGENESIS IN CANCER THERAPY. Journal of Pharma Research. 2019

9. Lee $\mathrm{CY}$, Chen CC, Liou HH. Levetiracetam inhibits glutamate transmission through presynaptic $P / Q$-type calcium channels on the granule cells of the dentate gyrus. British Journal of Pharmacology. 2009;158(7):1753-62.

10. Kamili C, Kakataparthy RS, Vattikutti UM, Chidrawar V, Ammineni S. Antiproliferative and anti-angiogenic activities of ion-channel modulators: In-ovo, in-vitro and in-vivo study. Asian Pacific Journal of Tropical Biomedicine. 2017;7(6):555-62.

11. Lang F, Stournaras C. Ion channels in cancer: Future perspectives and clinical potential. Philosophical Transactions of the Royal Society B: Biological Sciences. 2014;369(1638):20130108.

12. Kimmel CB, Ballard WW, Kimmel SR, Ullmann B, Schilling TF. Stages of embryonic development of the zebrafish. Developmental Dynamics. 1995;203(3):253-310.

13. Raman K. Cytotoxicity and Cell Viability with MTT Assay Protocol. Retrieved from http://scigine.com/blog/cell-viability-cytotoxic-mtt-assay/

14. A549 Cell Subculture Protocol -A549 Cell Line: Cell Culture and Transfection Protocol A549.com. 2020. [Cited 19 April 2020]. Available from: http://www. a549.com/cell-subculture-protocol/

15. Chassot B, Pury D, Jaźwińska A. Zebrafish fin regeneration after cryoinjuryinduced tissue damage. Biology Open. 2016;5(6):819-28.

16. Hlushchuk R, Brönnimann D, Shokiche CC, Schaad L, Triet R, Jazwinska A, et al. Zebrafish Caudal Fin Angiogenesis Assay-Advanced Quantitative Assessment Including 3-Way Correlative Microscopy. PloS One. 2016;11(3):e0149281.

17. Bakkiyanathan A, Nathan JR, Ravikumar S, Gopalakrishnan TS, Aruldas FM, Malathi R. Anti-angiogenic effects of theophylline on developing zebrafish (Danio rerio) embryos. Biomedicine and Preventive Nutrition. 2012;2(3):174-8.

18. Fraser SP, Diss JK, Chioni AM, Mycielska ME, Pan H, Yamaci RF, et al. Voltage-gated sodium channel expression and potentiation of human breast cancer metastasis. Clinical Cancer Research. 2005;11(15):5381-9.

19. Fraser SP, Ozerlat-Gunduz I, Brackenbury WJ, Fitzgerald EM, Campbell TM, Coombes RC, et al. Regulation of voltage-gated sodium channel expression in cancer: hormones, growth factors and auto-regulation. Philosophical Transactions of the Royal Society B: Biological Sciences. 2014;369(1638):20130105.

20. Leanza L, Biasutto L, Managò A, Gulbins E, Zoratti M, Szabò I. Intracellular ion channels and cancer. Frontiers in physiology. 2013 Sep 3;4:227.

21. Nobel CS, Aronson JK, DenDobbelsteen DJV, Slater AF. Inhibition of $\mathrm{Na}+$ / $\mathrm{K}+$-ATPase may be one mechanism contributing to potassium efflux and cell shrinkage in CD95-induced apoptosis. Apoptosis. 2000;5(2):153-63. 
PICTORIAL ABSTRACT

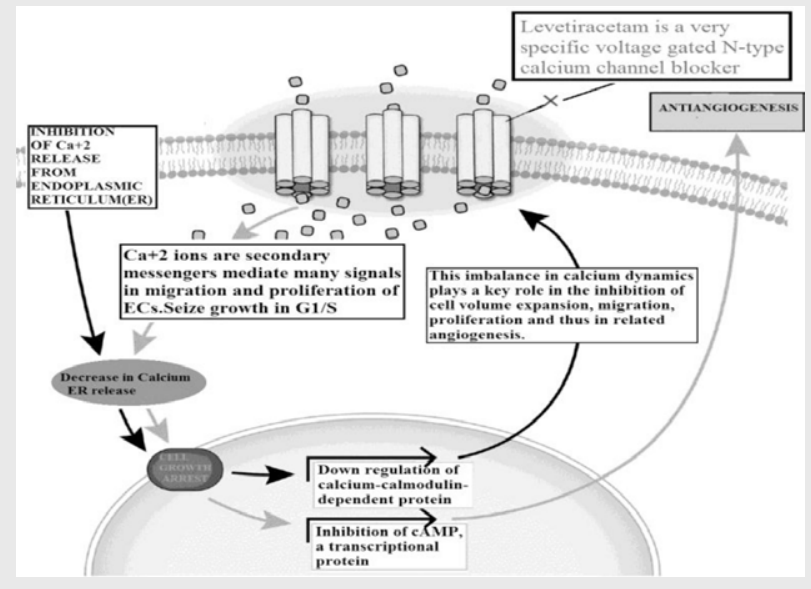

\section{SUMMARY}

Pathologically excessive angiogenesis can be the root cause of many diseased conditions. Ion channels on endothelium have a prime action in multi-stepped activity of angiogenesis. These ion channel functions are responsible for cell proliferation, migration, cell volume expansion, tubulogenesis resulting in micro neovascularization. This study aims to evaluate the antiangiogenic activity of Levetiracetam, a N-type voltage gated calcium channel blocker. Antiangiogenic activity of Levetiracetam was proven statistically significant in all the three methods; significant results were obtained at $20 \mu \mathrm{g}$ and $30 \mu \mathrm{g}$ in regeneration of fin growth in the Zebra fish fin assay. Whereas all the three doses i.e. $10 \mu \mathrm{g}, 20 \mu \mathrm{g}$ and $40 \mu \mathrm{g}$ have shown potent angiogenic vessel inhibition in the embryo assay. In the MTT assay similar result was observed with $20 \mu \mathrm{g}$ and $40 \mu \mathrm{g}$ of the drug. Structural modifications of the channel modulator tested in our study will develop endothelial cell embattled chemical leads with site specificity which reduces the side effects.

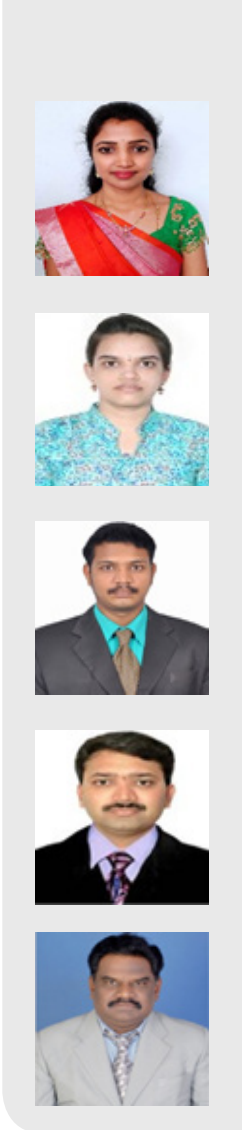

\section{About Authors}

Dr. Chandana Kamili has completed her Ph.D from JNTUH, Hyderabad in the year 2018, she has 10 years of experience in teaching and research in various capacities. She is currently working as Assistant Manager, Medical writing for Tata Consultancy Services, Mumbai, India. Her areas of research interest are molecular pathways of angiogenesis, study of modulators of angiogenesis and use of nanoparticles in angiogenesis.

Hima Sowmya Kandoti is a post-graduate (M.Pharm; Pharmacology) from CMR College of Pharmacy, Affiliated to Jawaharlal Nehru Technological University, Hyderabad, Telangana, India. She is currently working as Freelancer in Pharmaexcerption project at Excelra Knowledge Solutions, Hyderabad, India.

Sarolu Sunil Kumar is a post-graduate (M.Pharm; Pharmacology) from CMR College of Pharmacy, Affiliated to Jawaharlal Nehru Technological University, Hyderabad, Telangana, India. He is currently working as executive in drug regulatory affairs, Medchem International Limited, Hyderabad, India.

Dr. Suresh Merugu obtained his Ph.D from Indian Institute of Technology Roorkee, He has around 12 years of Teaching experience and 4 years of research experience in the fields of Advance Digital Image Processing, Colorimetry, Computer Vision, Sub-Pixel Classification, Data Mining Techniques and Space Sciences.

Dr. K. Abbulu has been severing the field of pharmacy for the past 28 years. He has to his credit 80 research publications and 45 presentations in seminar and conferences. He has guided $14 \mathrm{Ph} . \mathrm{D}$ scholars, 55 M.Pharm and 35 B.Pharmacy students.

Cite this article: Kamili C, Kandoti HS, Kumar SS, Merugu S, Konde A. Antiangiogenic Potential of Levetiracetam by Blocking N-type Voltage Gated Calcium Channels. Indian J of Pharmaceutical Education and Research. 2020;54(4):1056-61. 